\title{
O (DES) ENCONTRO ENTRE GÊNERO E INSTITUIÇÃO DE ENSINO: QUANDO COMEÇA O FIM DA DESIGUALDADE?
}

\author{
Edneusa Lima e Silva, FaSF, \\ evajom@gmail.com \\ Marcus Vinícius Barbosa, FaSF, \\ coordadm@fasfsul.com.br
}

PALAVRAS-CHAVE: gênero, educação, desigualdade, instituição de ensino, linguagem

\section{INTRODUÇÃO}

A transmissão das normas de conduta, dos valores sociais e regras acontecem por meio da linguagem, instrumento que nos permite expressar opiniões, ideias e pensamentos com conteúdos ideológicos. Por isso, ao falar, sempre o fazemos através da palavra dos outros: quando imitamos, ao fazer uma citação, quando fazemos uma tradução literal e quando nos posicionamos sobre determinado evento cotidiano ou fato histórico. Portanto, é pela linguagem que o sujeito se insere nas diferentes comunidades e, a escola, transmissora de valores, contribui para a formação de sujeitos, pois é uma instituição que os circunscreve, acompanhando-os nas diferentes fases do desenvolvimento. Historicamente, a escola é um espaço pautado pelas relações de gênero e, portanto, pelas desigualdades entre o masculino e o feminino. Questiona-se se as métricas adotadas refletem a verdadeira discussão sobre a identidade de gênero no ambiente escolar. Por isso, discussões de gêneros são importantes nesse espaço que possui como meta primeira: acolher a diversidade e todas as manifestações produzidas nos encontros entre meninos e meninas/rapazes e moças/homens e mulheres nos diferentes segmentos sociais. Sob essa perspectiva o objetivo deste trabalho é discutir o (des)encontro entre gênero e instituição de ensino, a partir dos discursos ideológicos sobre pertencer ao gênero masculino ou feminino

\section{METODOLOGIA}


Como metodologia, o trabalho pauta-se por uma pesquisa qualitativa de revisão bibliográfica, conforme aponta Marconi e Lakatos (1992), ancorado por fim a uma análise crítico conclusiva à luz das dimensões de pesquisa propostas por Novikoff (2010).

\section{DESCRIÇÕES, RESULTADOS E INTERPRETAÇÕES POSSIVEIS}

As características biológicas entre homens e mulheres são percebidas, valorizadas e interpretadas segundo as construções de gênero de cada sociedade e se referência pelo conjunto de representações construído, através de sua História, para atribuir significados, símbolos e diferenças para cada um dos sexos. De acordo com a literatura consultada, a escola que a sociedade ocidental moderna herdou separa adultos de crianças, ricos de pobres e meninos de meninas.

\section{CONSIDERAÇÕES FINAIS}

Herdamos, e agora, de muitas maneiras, mantemos uma importante instância de fabricação de meninos e meninas, homens e mulheres. $\mathrm{O}$ trabalho de conformação que tem início na família encontra eco e reforço na escola, que ensina maneiras próprias de se movimentar, de se comportar, de se expressar e, até mesmo, maneiras de preferir. Assim, quando os conflitos não são resolvidos, as questões relacionadas aos processos de julgamento social transpõem os muros escolares fortalecendo a desigualdade nos relacionamentos inter e intrapessoais. Alienados na sua condição, meninos e meninas/moças e rapazes reproduzirão a construção social e cultural de uma teoria do poder, isto é, as diferenças sociais e culturais entre homens e mulheres apresentam-se como reflexo de relações desiguais de poder no campo da vida pública e privada entre homens e mulheres.

\section{REFERÊNCIAS}

LOURO, Guacira Lopes. Gênero, sexualidade e educação: uma perspectiva pós-estruturalista. Petrópolis Vozes, 1997.

MARCONI, Marina de Andrade; LAKATOS, Eva Maria. Metodologia do trabalho científico. São Paulo: Editora Atlas, 1992. 4a ed.

NOVIKOFF, Cristina. Dimensões Novikoff: um constructo para o ensino e aprendizado da pesquisa. In ROCHA, José Geraldo da; NOVIKOFF, Cristina (Orgs.). Desafios da práxis educacional na contemporaneidade. Rio de Janeiro: Espalhafato Comunicação, 2010. 